\title{
Laparoscopy in pediatric surgery: Implementation in Canada and supporting evidence
}

Victoria Sattarova ${ }^{a}$, Simon Eaton ${ }^{b}$, Nigel J Hallc, Eveline Lapidus-Krola, Augusto Zania, Agostino Pierroa

[a] Division of General and Thoracic Surgery, The Hospital for Sick Children, University of Toronto, Toronto, Ontario, Canada

[b] UCL Institute of Child Health, London, United Kingdom

[c] Faculty of Medicine, University of Southampton, Southampton, United Kingdom

Address for correspondence and reprint requests

Dr. Agostino Pierro, MD, FRCS(Engl), FRCS(Ed), FAAP

Division Head, Paediatric Surgery

Robert M. Filler Professor of Surgery

University of Toronto, Canada

The Hospital for Sick Children

1526-555 University Ave

Toronto, ON M5G 1X8, Canada

Phone +1 4168137340

Fax +1 416-813-7477

agostino.pierro@sickkids.ca 


\section{Abstract}

Background/Purpose: To assess the diffusion of laparoscopy usage in Canadian pediatric centers and the relationship between uptake of laparoscopic surgery and the level of evidence supporting its use.

Methods: National data on four pediatric laparoscopic operations (appendectomy, pyloromyotomy, cholecystectomy, splenectomy) were analyzed using the Canadian Institute for Health Information Discharge Database (20022013). The highest level of evidence to support the use of each procedure was identified from Cochrane, Embase, and Pubmed databases. Chi-square test for trend was used to determine significance and time to plateau.

Results: There were 28,843 operations (open: 12,048; laparoscopic: 16,795). Use of laparoscopic procedures increased over time $(\mathrm{p}<0.0001)$. A plateau was reached for cholecystectomy (2006), splenectomy (2007) and appendectomy (2012), but not for pyloromyotomy. Laparoscopic pyloromyotomy in 2013 remains less diffused than the other procedures $(p<0.0001)$. Laparoscopic appendectomy and pyloromyotomy are supported by level-1a evidence in children whereas cholecystectomy and splenectomy are supported by level-1a evidence in adults but level-3 in children.

Conclusions: In Canada, it has taken a long time to reach high-level implementation of laparoscopic surgery in children. Laparoscopic cholecystectomy first reached plateau, whereas laparoscopic pyloromyotomy continues to increase but remains low despite high level of evidence in support of its usage compared to open surgery. 


\section{Introduction}

During the last two decades, one of the major innovations in general surgery has been the introduction of laparoscopy. Although randomized controlled trials (RCT) [1] and systematic reviews [2] have been performed to assess the benefit of laparoscopic versus open surgery in children, the uptake of laparoscopic surgery in children has been slower than in adults. Contributory factors include patient size, rarity of the diseases, training of attending surgeons [3] and learning curve [4]. Interestingly, te Velde et al have reported an increase in the proportion of laparoscopic procedures that can be performed safely and successfully from 60\% in 1998 to $81 \%$ in 2005 [3]. Despite this reported increase over time, there are no published data regarding the implementation of laparoscopy into routine practice in children and no parallel analysis of the evidence corresponding to laparoscopy in surgical practice.

We therefore sought to assess: (i) the diffusion curve of laparoscopic surgical procedures in Canadian pediatric hospitals and departments of pediatric surgery and to determine if a plateau was reached; (ii) the relationship between the uptake of laparoscopic surgery and the level of evidence supporting its use.

\section{Methods}

\subsection{Study Design}

This study was conducted with the approval of the Hospital for Sick Children Research Ethics Board (100045867). We evaluated 4 pediatric operations, which can be performed laparoscopically in children: appendectomy, 
pyloromyotomy, cholecystectomy, and splenectomy. A 12-year analysis (20022013) of these operations was carried out nationally using data from the Canadian Institute for Health Information (CIHI) Canadian Discharge Abstract Database (all provinces excluding Quebec since the Database does not include this province [https://www.cihi.ca/en/types-of-care/hospital-care/acutecare/dad-metadata]) in 11 Canadian specialist pediatric surgery centers (10 pediatric hospitals and 1 pediatric surgery department). CIHI codes were used for searching and translated to International Statistical Classification of Diseases (ICD) and Canadian Classification of Health Interventions (CCI) codes for identification of the hospital procedures (Appendix). Anonymity in relation to hospital source was maintained. Information collected included: year of surgery, procedure type, and laparoscopic or open procedure.

\subsection{Level of evidence}

Highest level of evidence available that related to each procedure was identified from the Cochrane Central, Embase, and Pubmed databases. Databases were searched from inception until June 2014. Searches were limited to English language publications comparing the traditional versus laparoscopic procedures (appendectomy, pyloromyotomy, cholecystectomy, splenectomy) that included participants 0-18 years of age. Evidence based surgery was classified according to Oxford Centre for Evidence-Based Medicine (OCEBM) Levels of Evidence Working Group (Table 1)[5].

\subsection{Statistical Analysis}


Differences between groups (surgical procedures) were evaluated using Chi square analysis. Bonferroni correction was used for multiple comparisons. Chi square test for trend was used to evaluate changes of the percentage of operations performed laparoscopically over time. Plateau was defined as the first year in which the Chi square test for trend did not indicate a significant increase in proportion of specific operation performed laparoscopically. A $p$ value of $<0.05$ was considered significant.

\section{Results}

\subsection{Laparoscopy diffusion curve trends in 11 pediatric centers in Canada}

When considering the four procedures: appendectomy, pyloromyotomy, cholecystectomy and splenectomy, there were a total of 28,843 operations (open: 12,048 (41.8\%); laparoscopic: 16,795 (58.2\%)) performed in 11 Canadian pediatric centers evaluated in the years 2002-2013. The change in proportion of each procedure performed laparoscopically over time is shown in Fig. 1. The proportion of each procedure performed using the open and laparoscopic approaches overall during the study period is shown in Table 2.

\subsection{Appendectomy}

Of the four procedures assessed, $73.4 \%$ were appendectomies. The use of laparoscopic appendectomy significantly increased with time $(\mathrm{p}<0.0001$, Fig. 1). In the first year of our analysis (2002), 29.3\% appendectomies were performed laparoscopically and by 2013 as many as $83.6 \%$ were performed laparoscopically. A plateau was reached for laparoscopic appendectomy in 2012 (Fig. 1). Laparoscopic appendectomy is supported by level 1a evidence in 
children from systematic review of RCTs [6] and meta-analysis of randomized and non-randomized trials - Aziz et al., 2006 [7].

\subsection{Pyloromyotomy}

Pyloromyotomy constituted $15.9 \%$ of the four procedures performed during the study period. The use of laparoscopic pyloromyotomy significantly increased with time ( $\mathrm{p}<0.0001$, Fig. 1). In 2002, 5.9\% of pyloromyotomies were performed laparoscopically and 37.2\% in 2013 (Fig. 1.). In 2013, the proportion of pyloromyotomies performed laparoscopically is significantly lower than the other three procedures $(\mathrm{p}<0.001$, Fig. 1). A plateau was not reached for laparoscopic pyloromyotomy in the study period. Laparoscopic pyloromyotomy is supported by level 1a evidence in the pediatric population: Meta-analysis of RCTs - Jia et al., 2011 [8], Meta analysis of RCTs - Oomen et al., 2012 [9].

\subsection{Cholecystectomy}

Cholecystectomy constituted $8.2 \%$ of the four procedures performed. The use of laparoscopic cholecystectomy significantly increased with time $(\mathrm{p}<0.0001$, Fig. 1). In $200282.9 \%$ of cholecystectomies were performed laparoscopically and 89.4\% in 2013 (Fig. 1). A plateau was reached for laparoscopic cholecystectomy in 2006 (Fig. 1). The highest level of evidence in children supporting laparoscopic cholecystectomy is $3 \mathrm{~b}$ : retrospective case-control studies - Kim et al., 1995 [10], Al-Salem et al., 1997 [11], Miltenburg et al., 2001 [12].

\subsection{Splenectomy}


Splenectomy constituted $2.5 \%$ of the four procedures analyzed. The implementation of laparoscopic splenectomy significantly increased with time (p<0.0001, Fig. 1). In $200213.6 \%$ of splenectomies were performed laparoscopically and 73.0\% in 2013 (Fig. 1). A plateau was reached for laparoscopic splenectomy in 2007 (Fig. 1). The highest level of evidence in children supporting LS is 3a: Review of retrospective case-control studies - Bax et al., 2001 [13]; 3b: Retrospective case-control studies - Yoshida et al., 1995 [14], Hicks et al., 1996 [15], Curran et al., 1998 [16], Rescorla et al., 1998 [17], Wood et al., 2011 [18].

\subsection{Inter-hospital laparoscopy diffusion curve trends}

An analysis of the three most common procedures (appendectomy, pyloromyotomy, cholecystectomy) showed that there is considerable variation between the pediatric centers in the use of laparoscopy (Fig. 2A-C). The sample size for the splenectomy procedure for each pediatric center was too small to represent the inter-hospital trends in the form of a meaningful graph.

\section{Discussion}

This study is the first to report the diffusion curve over a 12-year period in pediatric centers across Canada for four laparoscopic pediatric procedures: appendectomy, pyloromyotomy, cholecystectomy, and splenectomy. Additionally, we set out to assess the corresponding level of evidence and determined the highest level of evidence supporting each laparoscopic technique. 
Since the early 1980s, minimally invasive surgery has revolutionized adult surgical practice and yet there has been marked delay in its adoption to pediatric surgery. The implementation of laparoscopy in pediatric procedures has been made feasible with the advent of customized technological tools suitable for smaller patients as well as adequate surgical training in overcoming the learning curve $[3,19]$. Now a wide range of procedures are performed laparoscopically [20] ranging from those performed on infants to those performed on older children and adolescents. Today, medicine is increasingly being governed by evidence-based practice, which has been defined as: "the integration of best research evidence with clinical expertise and patient values" [21]. The prospective RCT performed to eliminate selection, allocation, and performance bias has been established as the highest level of evidence [5]. We previously reported that although evidence-based paediatric surgical practice has improved over the years, more than a third of the surgical procedures still lack sufficient evidence-based literature support [22]. With the present study, we confirmed that appendectomy and pyloromyotomy were supported by RCTs performed in children, yet cholecystectomy and splenectomy were not.

In the pediatric population, appendectomy is one of the most common surgical procedures. In our series $73.4 \%$ of the procedures were appendectomies. Our analysis shows that since 2002, the use of laparoscopic appendectomy has significantly increased with time from $29.3 \%$ of appendectomies performed laparoscopically, and reached a plateau in the year 2012. In the most recent year of analysis (2013) 83.6\% of appendectomies were operated on using the 
laparoscopic technique. Our results are comparable to those reported in a U.S. study: pediatric and adult data gathered from the National Inpatient Sample during 2004-2011 [23]. They report an increase in the use of laparoscopic appendectomy in children from 41.4\% (2004) to 73.4\% (2011) and similarly in adults, an increase from $45.5 \%$ (2004) to $76.9 \%$ (2011). Interestingly, there is considerable variation between the uptake of laparoscopic appendectomy in pediatric centers across Canada (Fig. 2A). In 2013, laparoscopic appendectomy is implemented in one center in $<50 \%$ of cases, in one center between $50 \%-75 \%$ of cases, in three centers between $76 \%-90 \%$ of cases, and in five centers $>90 \%$ of cases. The implementation of laparoscopic appendectomy for treatment of appendicitis in children is supported by the availability of the highest level of evidence: 1a. Although laparoscopic appendectomy was first described in adults in 1983 [24], it was only described in children 8 years later [25]. Likewise, there was considerable lag between the first published adult RCT [26] and pediatric RCT comparing laparoscopic and open appendectomy [27]. In Canada, a plateau in the diffusion curve of laparoscopic appendectomy was reached 16 years after the first pediatric RCT was published. Despite the popularity of the minimally invasive procedure and the existence of $1 \mathrm{a}$ evidence supporting its implementation, laparoscopic appendectomy is not implemented in $100 \%$ of the cases. The therapeutic advantages of the laparoscopic technique include: lower risk of wound infection [6, 28], reduced postoperative pain [6], [28] shorter length of hospital stay $[6,28]$, and quicker return to normal activities. The disadvantages of laparoscopic appendectomy as compared to the open technique include longer duration of the operation [6] and higher costs within hospital stay were found in two trials [6]. Although the laparoscopic procedure can lessen 
postoperative morbidity [28], it is not considered "wrong" to perform appendectomy using the open technique because the difference between the two techniques isn't great. Patient characteristics as well as the surgeon's experience with laparoscopic procedures are both considered when making the decision between laparoscopic and open appendectomy.

Of the four procedures we analyzed, pyloromyotomy is the second most common, constituting $15.9 \%$ of the operations performed in 2002-2013. Additionally, laparoscopic pyloromyotomy has the lowest implementation in 2013 of the four procedures (Fig. 1) $(\mathrm{p}<0.0001)$, has not reached a plateau and it continues to increase with time ( $\mathrm{p}<0.0001$, Fig. 1). Laparoscopic pyloromyotomy for hypertrophic stenosis in children was first documented in 1991 [29] when it was described as feasible and safe. It is remarkable that 22 years later, in 2013, despite the availability of level 1a studies in children assessing laparoscopic versus open pyloromyotomy, our findings show that as few as $37.2 \%$ of pyloromyotomies in Canada are performed laparoscopically. Meanwhile, a single-center study (Children's Hospital Colorado) reports an increase of laparoscopic pyloromyotomy from 10\% (2002) to 98\% (2012) [30]. Oomen and colleagues report values closer to our findings: $31 \%$ of pyloromyotomies were performed laparoscopically in the years 2002-2008, and that there was a learning curve of 35 procedures [4]. There is variation amongst the 11 pediatric centers in laparoscopic pyloromyotomy implementation (Fig. 2B). In 2013, laparoscopic pyloromyotomy is implemented in six centers in $<50 \%$ of cases, in two centers in $50 \%-75 \%$ of cases, in one center in $76 \%-90 \%$ and in one center in $>90 \%$ of cases. Although statistically significant differences have been identified 
in level 1a evidence comparing laparoscopic and open pyloromyotomy [1], these differences translate into a small clinically significant benefit in patient outcomes from the laparoscopic approach. Thus, low implementation may be attributed to this. While advantages of laparoscopic pyloromyotomy include better cosmetic results [31] and overall the laparoscopic procedure was reported as less expensive than the open one [32], there was no statistically significant difference in complication rates $[9,31]$ or operating time between the two procedures $[8$, 31]. There are varying findings regarding length of hospital stay and time to full feeds, some studies reporting shorter duration in laparoscopic pyloromyotomy $[9,32]$, while others reporting that there are no differences $[8,31]$.

Of the four procedures in our report, cholecystectomy is the third most common, constituting $8.2 \%$ of the total. In 2013 , as many as $89.4 \%$ of procedures were laparoscopic cholecystectomy (Fig. 1), and of the total cholecystectomies, $86.4 \%$ were performed laparoscopically (Table 2). This proportion is comparable to an earlier U.S. study in children (1996-2003) reporting that overall 84\% of cholecystectomies were laparoscopic [33]. There tends to be less inter-center variation in laparoscopic cholecystectomy than in laparoscopic appendectomy and laparoscopic pyloromyotomy, as all centers implement laparoscopic cholecystectomy in more than $50 \%$ of the cases. Additionally, in 2013, laparoscopic cholecystectomy was implemented in one center in $50 \%-75 \%$ of cases, in two centers in $76 \%-90 \%$ and in seven centers in $>90 \%$ of cases (Fig. 2C). Our results show that the proportion of laparoscopic cholecystectomy cases significantly increased with time, and of the four procedures in our study, laparoscopic cholecystectomy was the earliest to reach a plateau (2006) (Fig. 1), 
15 years since it was first described in children. Strikingly, despite the high level of laparoscopic cholecystectomy implementation in children, high level of evidence in children is lacking, but does exist in adult participants. Although laparoscopic cholecystectomy in children can be performed safely [12], the highest level of evidence in children remains $3 \mathrm{~b}$. While longer operative time in the laparoscopic approach has been reported in children $[11,12]$, a study by Kim and colleagues describes that there is a learning curve to laparoscopic cholecystectomy and by the second year of the study there was no significant difference in the average operative time between laparoscopic and open cholecystectomy or in the complication rate [10]. Advantages of the laparoscopic technique include significantly lower postoperative analgesic requirements [10], shorter length of hospital stay $[10,11]$, and lower overall cost due to shorter length of hospitalization [10].

Of the four procedures studied, splenectomy is the least common constituting $2.5 \%$ of all the operations in our report. It is performed as a treatment in children for hematolgic diseases including: hereditary spherocytosis, idiopathic thrombocytopenic purpura, sickle cell disease, and autoimmune hemolytic anemia. Laparoscopic splenectomy was first described in adults in 1991 [34] and two years later in children [35]. The minimally invasive procedure has been established through case-control studies as one that can be executed safely and effectively in children [14-16], and it was recognized that it had offered several distinct advantages in pediatric surgery: shorter length of hospital stay $[16,18]$, shorter duration of postoperative analgesia [36, 37], and better cosmesis [14, 16]. Laparoscopic splenectomy has become the preferred method of treatment 
and in 2002 was reported as the gold standard procedure in children [38]. Surprisingly, in that year our results show that only $13.6 \%$ of splenectomies were performed laparoscopically (Fig. 1). While a high majority of splenectomies in 2013 were performed laparoscopically (73\%, Fig. 1), this minimally invasive technique is not supported by highest level of evidence. This could be related to the fact that laparoscopic splenectomy has been reported as safe and as an advantageous procedure in experienced surgeons despite the lack of level 1 evidence by the European Association for Endoscopic Surgery [39]. Laparoscopic splenectomy is an advanced laparoscopic procedure and there have been several challenges that were overcome throughout the years with surgical experience. The operative time has been reduced and had become comparable to the open technique $[18,39,40]$, while patients with splenomegaly can be operated on safely and successfully as well $[18,39]$. In an Urban tertiary children's hospital in the U.S., 83.9\% of pediatric splenectomy cases performed between 2000-2008 were done laparoscopically [18] and since 2005, there were no open splenectomy cases. In relation to this, the overall implementation of laparoscopic splenectomy in our study seems lower and our analysis takes place during later years. It is interesting that in our study the plateau for splenectomy is reached earlier (2007) compared to appendectomy (2012). One possible reason for this difference in timing could be related to the fact that splenectomy in children is usually performed by surgeons with extensive experience who can be prone to adopt in their practice new techniques with benefits for the child and avoidance of a large abdominal incision.

Although level 3 evidence has limitations such as potential bias induced by the lack of procedure randomization and blinding, it is important to address the 
ethical implications that are associated with performing RCTs on procedures that have become quickly accepted and widely implemented. This stemmed from strong obvious benefits of the lower morbidity associated with minimally invasive surgery and it was even more exaggerated in cholecystectomy and splenectomy since the techniques required larger incisions in the open approach. Hence, an alternative to RCTs was used and researchers performed observational studies of laparoscopic cholecystectomy and laparoscopic splenectomy $[41,42]$.

The CIHI data does not include the reason for performing an operation in the open fashion versus laparoscopically. It is possible that factors not available in this database may have influenced the decision on which type of surgery was in the best interest of the child being operated.

Limitations of our study include: (i) not having access to conversion data from laparoscopic to the open approach. (ii) excluding adult hospitals where operations in children could be performed such as appendectomy and cholecystectomy. We do not know how many patients undergo these operations in community adult hospitals compared to children's hospitals and this information would influence the diffusion curve of laparoscopy. (iii) not including data on patients' age to determine whether the diffusion curves of laparoscopy in adolescents are comparable to those in adults. It would be beneficial in the future to analyze the indication for surgery especially for cholecystectomy and splenectomy, as well as performing a sub-analysis on the patient age groups.

\section{Conclusion}


The use of laparoscopy from 2002 to 2013 for appendectomy, pyloromyotomy, cholecystectomy, and splenectomy varies greatly $(2 \%-92 \%)$ in the whole of Canada. The use of all 4 laparoscopic procedures significantly increased. A plateau in the use of laparoscopy was reached for cholecystectomy, splenectomy and appendectomy. Meanwhile, there was no plateau for pyloromyotomy as there still is a trend in increasing the use of laparoscopic pyloromyotomy. Laparoscopic appendectomy and laparoscopic pyloromyotomy are supported by the highest level of evidence in children. Despite the high level of evidence, the use of laparoscopic pyloromyotomy in 2013 remains lower than the other 3 procedures.

Achieving a high, steady level of implementation of novel laparoscopic procedures in children has taken 15-21 years since their introduction. This nationwide epidemiological study provides a benchmark for the use of laparoscopy and highlights the need for the implementation of evidence based surgical practice. 


\section{Acknowledgements}

This work has been supported by funds from the Robert M Filler Chair of

Pediatric Surgery and a summer studentship grant (VS) from the Department of Surgery and Perioperative Services at the Hospital for Sick Children.

SE was supported by Great Ormond Street Hospital Children's Charity. 


\section{References}

[1] Hall NJ, Pacilli M, Eaton S, et al: Recovery after open versus laparoscopic pyloromyotomy for pyloric stenosis: a double-blind multicentre randomised controlled trial. Lancet 2009;373:390-398.

[2] Dingemann J, Ure BM: Systematic review of level 1 evidence for laparoscopic pediatric surgery: do our procedures comply with the requirements of evidence-based medicine? Eur J Pediatr Surg 2013;23:474-479.

[3] te Velde EA, Bax NMA, Tytgat SHAJ, et al: Minimally invasive pediatric surgery: Increasing implementation in daily practice and resident's training. Surg Endosc 2008;22:163-166.

[4] Oomen MWN, Hoekstra LT, Bakx R, et al: Learning curves for pediatric laparoscopy: How many operations are enough? The Amsterdam experience with laparoscopic pyloromyotomy. Surg Endosc 2010;24:1829-1833.

[5] OCEBM Levels of Evidence Working Group. Oxford Centre for EvidenceBased Medicine 2009. http://www.cebm.net/oxford-centre-evidencebased-medicine-levels-evidence-march-2009/.

[6] Sauerland S, Jaschinski T, Neugebauer EA: Laparoscopic versus open surgery for suspected appendicitis. Cochrane Database Syst Rev 2010;10:CD001546.

[7] Aziz 0, Athanasiou T, Tekkis PP, et al: Laparoscopic Versus Open Appendectomy in Children. Ann Surg 2006;243:17-27.

[8] Jia W-Q, Tian J-H, Yang K-H, et al: Open versus laparoscopic pyloromyotomy for pyloric stenosis: A meta-analysis of randomized controlled trials. Eur J Pediatr Surg 2011;21:77-81.

[9] Oomen MWN, Hoekstra LT, Bakx R, et al: Open versus laparoscopic pyloromyotomy for hypertrophic pyloric stenosis: a systematic review and meta-analysis focusing on major complications. Surg Endosc 2012;26:2104-2110.

[10] Kim PC, Wesson D, Superina R, et al: Laparoscopic cholecystectomy versus open cholecystectomy in children: Which is better? J Pediatr Surg 1995;30:971-973.

[11] Al-Salem AH, Qaisaruddin S, Al-Abkari H, et al: Laparoscopic versus open cholecystectomy in children. Pediatr Surg Int 1997;12:587-590. 
[12] Miltenburg DM, Schaffer III RL, Palit TK, et al: Laparoscopic cholecystectomy in children: Is it better than open surgery? Pediatr Endosurg Innov Tech 2001;5:13-17.

[13] Bax NMA, Van der Zee DC: Laparoscopic splenectomy: Is this the way to do it? Pediatr Endosurg Innov Tech 2001;5:281-286.

[14] Yoshida K, Yamazaki Y, Mizuno R, et al: Laparoscopic splenectomy in children. Preliminary results and comparison with the open technique. Surg Endosc 1995;9:1279-1282.

[15] Hicks BA, Thompson WR, Rogers ZR, et al: Laparoscopic splenectomy in childhood hematologic disorders. J Laparoendosc Surg 1996;6:S31-S34.

[16] Curran TJ, Foley MI, Swanstrom LL, et al: Laparoscopy improves outcomes for pediatric splenectomy. J Pediatr Surg 1998;33:1498-1500.

[17] Rescorla FJ: Laparoscopic splenectomy in childhood. Pediatr Endosurg Innov Tech 1998;2:167-175.

[18] Wood JH, Partrick DA, Hays T, et al: Contemporary pediatric splenectomy: continuing controversies. Pediatr Surg Int 2011;27:1165-1171.

[19] Jackson HT, Kane TD: Advances in Minimally Invasive Surgery in Pediatric Patients. Adv Pediatr 2014;61:149-195.

[20] Blatnik JA, Ponsky TA: Advances in minimally invasive surgery in pediatrics. Curr Gastroenterol Rep 2010;12:211-214.

[21] Sackett D, Rosenberg WMC, Gray JAM, et al: Evidence based medicine: what it is and what it isn't. BMJ 1996;312:71-72.

[22] Zani-Ruttenstock E, Zani A, Bullman E, et al: Are paediatric operations evidence based? A prospective analysis of general surgery practice in a teaching paediatric hospital. Pediatr Surg Int 2015;31:53-59.

[23] Masoomi H, Nguyen NT, Dolich MO, et al: Laparoscopic Appendectomy Trends and Outcomes in the United States: Data from the Nationwide Inpatient Sample ( NIS ), 2004 - 2011. Am Surg 2014;80:1074-1077.

[24] Semm K. Endoscopic Appendectomy. Endoscopy 1983;15:59-64.

[25] Valla JS, Limonne B, Valla V, et al: Laparoscopic Appendectomy in Children: Report of 465 Cases. Surg Laparosc Endosc 1991;1:166-172.

[26] Attwood SE, Hill AD, Murphy PG, et al: A prospective randomized trial of laparoscopic versus open appendectomy. Surgery 1992;112:497-501. 
[27] Lejus C, Delile L, Plattner V, et al: Randomized, single-blinded trial of laparoscopic versus open appendectomy in children: effects on postoperative analgesia. Anesthesiology 1996;84:801-806.

[28] Saha N Rahman MA, Islam MK, et al: Comparison of post operative morbidity between laparoscopic and open appendectomy in children. Mymensingh Med J 2010;19:348-352.

[29] Alain JL, Grousseau D, Terrier G. Surgical Endoscopy Extramucosal pyloromyotomy by laparoscopy. Surg Endosc 1991;5:174-175.

[30] Acker SN, Staulcup S, Partrick DA, et al: Evolution of Minimally Invasive Techniques Within an Academic Surgical Practice at a Single Institution. J Laparoendosc Adv Surg Tech 2014;24:806-810.

[31] Siddiqui S, Heidel RE, Angel CA, et al: Pyloromyotomy: Randomized control trial of laparoscopic vs open technique. J Pediatr Surg 2012;47:93-98.

[32] Carrington EV, Hall NJ, Pacilli M, et al: Cost-effectiveness of laparoscopic versus open pyloromyotomy. J Surg Res 2012;178:315-320.

[33] Balaguer EJ, Price MR, Burd RS: National Trends in the Utilization of Cholecystectomy in Children. J Surg Res 2006;134:68-73.

[34] Delaitre B, Maignien B: Splenectomy by the Laparoscopic Approach. Report of a Case. Presse Med 1991;20:2263.

[35] Tulman S, Holcomb GW 3rd, Karamanoukian HL, et al: Pediatric laparoscopic splenectomy. J Pediatr Surg 1993;28:689-692.

[36] Rescorla FJ, Breitfeld PP, West KW, et al: A case controlled comparison of open and laparoscopic splenectomy in children. Surgery 1998;124:670676.

[37] Farah RA, Rogers ZR, Thompson WR, et al: Comparison of laparoscopic and open splenectomy in children with hematologic disorders. J Pediatr 1997;131:41-46.

[38] Rescorla FJ, Engum SA, West KW, et al: Laparoscopic splenectomy has become the gold standard in children. Am Surg 2002;68:292-297.

[39] Habermalz B, Sauerland S, Decker G, et al: Laparoscopic splenectomy: the clinical practice guidelines of the European Association for Endoscopic Surgery (EAES). Surg Endosc 2008;22:821-848.

[40] Rescorla FJ, West KW, Engum SA, et al: Laparoscopic splenic procedures in children: experience in 231 children. Ann Surg 2007;246:683-687. 
[41] Neugebauer E, Troidl $\mathrm{H}$, Spangenberger $\mathrm{W}$, et al: Conventional versus laparoscopic cholecystectomy and the randomized controlled trial. BJS 1991;78:150-154.

[42] Peter SDS, Ostlie DJ: The necessity for prospective evidence for single-site umbilical laparoscopic surgery. Semin Pediatr Surg 2011;20:232-236. 


\section{Figure legends}

Fig. 1. Diffusion curves showing the percentage of procedures performed laparoscopically in 11 pediatric centers in Canada; * indicates plateau.

Fig. 2. Diffusion Curves for [A] appendectomy; [B] pyloromyotomy and [C] cholecystectomy performed at 11 pediatric centers in Canada. 
Table 1. Oxford Centre for Evidence-Based Medicine Levels of Evidence

\begin{tabular}{|l|l|}
\hline Level & Type of Study \\
\hline $1 \mathrm{a}$ & SR/MA of RCTs \\
\hline $1 \mathrm{~b}$ & Individual RCT \\
\hline $2 \mathrm{a}$ & SR/MA of cohort studies \\
\hline $2 \mathrm{~b}$ & $\begin{array}{l}\text { Individual cohort study } \\
\text { (including low quality RCT) }\end{array}$ \\
\hline $3 \mathrm{a}$ & $\begin{array}{l}\text { SR/MA of case-control } \\
\text { studies }\end{array}$ \\
\hline $3 \mathrm{~b}$ & $\begin{array}{l}\text { Individual case-control } \\
\text { Study }\end{array}$ \\
\hline 4 & $\begin{array}{l}\text { Case series (and poor quality } \\
\text { cohort and case-control } \\
\text { studies) }\end{array}$ \\
\hline 5 & Expert opinion \\
\hline
\end{tabular}

Abbreviations: RCT, randomized controlled trial; SR, systematic review; MA, meta-analysis. 
Table 2. Number of laparoscopic and open procedures performed in 11 Canadian pediatric centers.

\begin{tabular}{|l|l|l|}
\hline Procedure & $\begin{array}{l}\text { Laparoscopic } \\
\text { n, (\%) }\end{array}$ & $\begin{array}{l}\text { Open n, } \\
\text { (\%) }\end{array}$ \\
\hline Appendectomy & $13392(63.3)$ & $\begin{array}{l}7768 \\
(36.7)\end{array}$ \\
\hline Pyloromyotomy & $895(19.5)$ & $\begin{array}{l}3691 \\
(80.5)\end{array}$ \\
\hline Cholecystectomy & $2051(86.4)$ & $322(13.6)$ \\
\hline Splenectomy & $457(63.1)$ & $267(36.9)$ \\
\hline
\end{tabular}


Appendix: Canadian Institute for Health Information (CIHI) codes used for searching. These codes were translated to International Statistical Classification of Diseases (ICD) and Canadian Classification of Health Interventions (CCI) codes for identification of hospital procedures.

\begin{tabular}{|c|c|c|}
\hline $\begin{array}{l}\text { CIHI } \\
\text { SEARCH } \\
\text { CODE }\end{array}$ & $\begin{array}{l}\text { ICD/CCI } \\
\text { code }\end{array}$ & DESCRIPTION \\
\hline 1NV89DA & $\begin{array}{l}\text { 1.NV.89.D } \\
\text { A }\end{array}$ & $\begin{array}{l}\text { Excision total, appendix using endoscopic } \\
\text { [laparoscopic] approach }\end{array}$ \\
\hline 1NV89LA & $\begin{array}{l}\text { 1.NV.89.L } \\
\text { A }\end{array}$ & Excision total, appendix using open approach \\
\hline 1NE72DA & $\begin{array}{l}\text { 1.NE.72.D } \\
\text { A }\end{array}$ & $\begin{array}{l}\text { Release, pylorus endoscopic [laparoscopic] approach } \\
\text { without concomitant vagotomy }\end{array}$ \\
\hline 1NE72EK & $\begin{array}{l}\text { 1.NE.72.E } \\
\mathrm{K}\end{array}$ & $\begin{array}{l}\text { Release, pylorus using endoscopic [laparoscopic] } \\
\text { approach with truncal vagotomy [e.g. vagotomy } \\
\text { NOS] }\end{array}$ \\
\hline 1NE72EL & 1.NE.72.EL & $\begin{array}{l}\text { Release, pylorus endoscopic [laparoscopic] approach } \\
\text { with proximal gastric vagotomy[includes: parietal } \\
\text { cell, highly selective vagotomy] }\end{array}$ \\
\hline 1NE72LA & $\begin{array}{l}\text { 1.NE.72.L } \\
\text { A }\end{array}$ & $\begin{array}{l}\text { Release, pylorus open approach without concomitant } \\
\text { vagotomy }\end{array}$ \\
\hline 1NE72VY & $\begin{array}{l}\text { 1.NE.72.V } \\
Y\end{array}$ & $\begin{array}{l}\text { Release, pylorus open approach with proximal } \\
\text { gastric vagotomy[includes: parietal cell, highly } \\
\text { selective vagotomy] }\end{array}$ \\
\hline 1NE72XN & $\begin{array}{l}\text { 1.NE.72.X } \\
\mathrm{N}\end{array}$ & $\begin{array}{l}\text { Release, pylorus open approach with truncal } \\
\text { vagotomy [ }\end{array}$ \\
\hline 10D89DA & $\begin{array}{l}\text { 1.0D.89.D } \\
\text { A }\end{array}$ & $\begin{array}{l}\text { Excision total, gallbladder endoscopic [laparoscopic] } \\
\text { approach without extraction (of calculi) } \\
\text { cholecystectomy alone }\end{array}$ \\
\hline $\begin{array}{l}\text { 10D89DTA } \\
\text { G }\end{array}$ & $\begin{array}{l}\text { 1.OD.89.D } \\
\text { T-AG }\end{array}$ & $\begin{array}{l}\text { Excision total, gallbladder using endoscopic } \\
\text { [laparoscopic] approach using laser probe }\end{array}$ \\
\hline $\begin{array}{l}\text { 10D89DTA } \\
\mathrm{M}\end{array}$ & $\begin{array}{l}\text { 1.0D.89.D } \\
\text { T-AM }\end{array}$ & $\begin{array}{l}\text { Excision total, gallbladder endoscopic [laparoscopic] } \\
\text { approach with extraction (of calculi) from bile ducts } \\
\text { using basket device }\end{array}$ \\
\hline 10D89DTAS & $\begin{array}{l}\text { 1.0D.89.D } \\
\text { T-AS }\end{array}$ & $\begin{array}{l}\text { Excision total, gallbladder using endoscopic } \\
\text { [laparoscopic] approach using electrohydraulic } \\
\text { probe }\end{array}$ \\
\hline $\begin{array}{l}\text { 10D89DTB } \\
\text { D }\end{array}$ & $\begin{array}{l}\text { 1.0D.89.D } \\
\text { T-BD }\end{array}$ & $\begin{array}{l}\text { Excision total, gallbladder using endoscopic } \\
\text { [laparoscopic] approach using balloon device }\end{array}$ \\
\hline $\begin{array}{l}\text { 10D89DTG } \\
\mathrm{X}\end{array}$ & $\begin{array}{l}\text { 1.0D.89.D } \\
\text { T-GX }\end{array}$ & $\begin{array}{l}\text { Excision total, gallbladder endoscopic [laparoscopic] } \\
\text { approach with extraction (of calculi) from bile ducts } \\
\text { using device NEC [e.g. forceps, metal probe] }\end{array}$ \\
\hline 10D89EC & $\begin{array}{l}1.0 D .89 . \mathrm{E} \\
\mathrm{C}\end{array}$ & $\begin{array}{l}\text { Excision total, gallbladder endoscopic [laparoscopic] } \\
\text { approach cholecystectomy with bile duct exploration } \\
\text { and no stones extracted }\end{array}$ \\
\hline 10D89LA & 1.0D.89.L & Excision total, gallbladder open approach without \\
\hline
\end{tabular}




\begin{tabular}{|c|c|c|}
\hline & $\mathrm{A}$ & extraction of calculi cholecystectomy alone \\
\hline 10D89PN & $\begin{array}{l}\text { 1.0D.89.P } \\
\mathrm{N}\end{array}$ & $\begin{array}{l}\text { Excision total, gallbladder robotic assisted } \\
\text { telemanipulation of tools [telesurgery] without } \\
\text { extraction of calculi cholecystectomy alone }\end{array}$ \\
\hline $\begin{array}{l}\text { 10D89SMA } \\
\mathrm{G}\end{array}$ & $\begin{array}{l}\text { 1.0D.89.S } \\
\text { M-AG }\end{array}$ & $\begin{array}{l}\text { Excision total, gallbladder using open approach using } \\
\text { laser probe }\end{array}$ \\
\hline $\begin{array}{l}\text { 10D89SMA } \\
\text { M }\end{array}$ & $\begin{array}{l}\text { 1.0D.89.S } \\
\text { M-AM }\end{array}$ & $\begin{array}{l}\text { Excision total, gallbladder using open approach using } \\
\text { basket device }\end{array}$ \\
\hline $\begin{array}{l}\text { 10D89SMA } \\
\mathrm{S}\end{array}$ & $\begin{array}{l}\text { 1.0D.89.S } \\
\text { M-AS }\end{array}$ & $\begin{array}{l}\text { Excision total, gallbladder using open approach using } \\
\text { electrohydraulic probe }\end{array}$ \\
\hline $\begin{array}{l}\text { 10D89SMB } \\
\text { D }\end{array}$ & $\begin{array}{l}\text { 1.0D.89.S } \\
\text { M-BD }\end{array}$ & $\begin{array}{l}\text { Excision total, gallbladder open approach with } \\
\text { extraction (of calculi) from bile ducts using balloon } \\
\text { device }\end{array}$ \\
\hline $\begin{array}{l}\text { 10D89SMG } \\
\mathrm{X}\end{array}$ & $\begin{array}{l}\text { 1.0D.89.S } \\
\text { M-GX }\end{array}$ & $\begin{array}{l}\text { Excision total, gallbladder open approach with } \\
\text { extraction (of calculi) from bile ducts using device } \\
\text { NEC [e.g. forceps, metal probe] }\end{array}$ \\
\hline 10D89TP & $\begin{array}{l}\text { 1.0D.89.T } \\
\mathrm{P}\end{array}$ & $\begin{array}{l}\text { Excision total, gallbladder open approach } \\
\text { cholecystectomy with bile duct exploration and no } \\
\text { stones extracted }\end{array}$ \\
\hline 10D57DA & $\begin{array}{l}\text { 1.0D.57.D } \\
\text { A }\end{array}$ & $\begin{array}{l}\text { Extraction, gallbladder using endoscopic } \\
\text { (laparoscopic) approach }\end{array}$ \\
\hline 10D57LA & $\begin{array}{l}\text { 1.0D.57.L } \\
\text { A }\end{array}$ & Extraction, gallbladder using open approach \\
\hline 10B89DA & $\begin{array}{l}\text { 1.0B.89.D } \\
\text { A }\end{array}$ & Excision total, spleen using endoscopic approach \\
\hline 10B89LA & $\begin{array}{l}\text { 1.0B.89.L } \\
\text { A }\end{array}$ & $\begin{array}{l}\text { Excision total, spleen using open [abdominal] } \\
\text { approach }\end{array}$ \\
\hline 10B89PF & 1.0B.89.PF & $\begin{array}{l}\text { Excision total, spleen using open posterior } \\
\text { [subcostal] approach }\end{array}$ \\
\hline 10B87DA & $\begin{array}{l}\text { 1.0B.87.D } \\
\text { A }\end{array}$ & $\begin{array}{l}\text { Excision partial, spleen endoscopic [laparoscopic] } \\
\text { approach using apposition technique for closure [e.g. } \\
\text { suturing] }\end{array}$ \\
\hline $\begin{array}{l}\text { 10B87DAA } \\
\text { G }\end{array}$ & $\begin{array}{l}\text { 1.0B.87.D } \\
\text { A-AG }\end{array}$ & $\begin{array}{l}\text { Excision partial, spleen endoscopic [laparoscopic] } \\
\text { approach using laser coagulation }\end{array}$ \\
\hline $\begin{array}{l}\text { 10B87DAW } \\
3\end{array}$ & $\begin{array}{l}\text { 1.0B.87.D } \\
\text { A-W3 }\end{array}$ & $\begin{array}{l}\text { Excision partial, spleen endoscopic [laparoscopic] } \\
\text { approach using fibrin glue }\end{array}$ \\
\hline 10B87DAX7 & $\begin{array}{l}\text { 1.0B.87.D } \\
\text { A-X7 }\end{array}$ & $\begin{array}{l}\text { Excision partial, spleen endoscopic [laparoscopic] } \\
\text { approach using chemocautery agent [e.g. topical } \\
\text { thrombin] }\end{array}$ \\
\hline $\begin{array}{l}\text { 10B87DAXX } \\
\text { E }\end{array}$ & $\begin{array}{l}\text { 1.OB.87.D } \\
\text { A-XX-E }\end{array}$ & $\begin{array}{l}\text { Excision partial, spleen endoscopic [laparoscopic] } \\
\text { approach using local flap [e.g. omental wrap] }\end{array}$ \\
\hline $\begin{array}{l}\text { 10B87DAXX } \\
\mathrm{N}\end{array}$ & $\begin{array}{l}\text { 1.OB.87.D } \\
\text { A-XX-N }\end{array}$ & $\begin{array}{l}\text { Excision partial, spleen using endoscopic } \\
\text { [laparoscopic] approach using synthetic tissue [e.g. } \\
\text { mesh] }\end{array}$ \\
\hline 10B87LA & $\begin{array}{l}\text { 1.0B.87.L } \\
\text { A }\end{array}$ & $\begin{array}{l}\text { Excision partial, spleen open [abdominal] approach } \\
\text { using apposition technique for closure [e.g. suturing] }\end{array}$ \\
\hline 10B87LAAG & $\begin{array}{l}\text { 1.0B.87.L } \\
\text { A-AG }\end{array}$ & $\begin{array}{l}\text { Excision partial, spleen using open [abdominal] } \\
\text { approach using laser coagulation }\end{array}$ \\
\hline
\end{tabular}




\begin{tabular}{|c|c|c|}
\hline $\begin{array}{l}\text { 10B87LAW } \\
2\end{array}$ & $\begin{array}{l}\text { 1.0B.87.L } \\
\text { A-W2 }\end{array}$ & $\begin{array}{l}\text { Excision partial, spleen using open [abdominal] } \\
\text { approach using collagen powder }\end{array}$ \\
\hline $\begin{array}{l}\text { 10B87LAW } \\
3\end{array}$ & $\begin{array}{l}\text { 1.0B.87.L } \\
\text { A-W3 }\end{array}$ & $\begin{array}{l}\text { Excision partial, spleen using open [abdominal] } \\
\text { approach using fibrin glue }\end{array}$ \\
\hline 10B87LAX7 & $\begin{array}{l}\text { 1.0B.87.L } \\
\text { A-X7 }\end{array}$ & $\begin{array}{l}\text { Excision partial, spleen open [abdominal] approach } \\
\text { using chemical cautery agent [e.g. topical thrombin] }\end{array}$ \\
\hline $\begin{array}{l}\text { 10B87LAXX } \\
\text { E }\end{array}$ & $\begin{array}{l}\text { 1.0B.87.L } \\
\text { A-XX-E }\end{array}$ & $\begin{array}{l}\text { Excision partial, spleen open [abdominal] approach } \\
\text { using local flap [e.g. omental wrap] }\end{array}$ \\
\hline $\begin{array}{l}\text { 10B87LAXX } \\
\mathrm{N}\end{array}$ & $\begin{array}{l}\text { 1.0B.87.L } \\
\text { A-XX-N }\end{array}$ & $\begin{array}{l}\text { Excision partial, spleen using open [abdominal] } \\
\text { approach using synthetic tissue [e.g. mesh] }\end{array}$ \\
\hline 10B87PF & 1.0B.87.PF & $\begin{array}{l}\text { Excision partial, spleen using open posterior } \\
\text { [subcostal] approach using apposition technique for } \\
\text { closure [e.g. suturing] }\end{array}$ \\
\hline 10B87PFAG & $\begin{array}{l}\text { 1.OB.87.PF } \\
\text {-AG }\end{array}$ & $\begin{array}{l}\text { Excision partial, spleen open posterior [subcostal] } \\
\text { approach using laser coagulation }\end{array}$ \\
\hline $\begin{array}{l}\text { 10B87PFW } \\
2\end{array}$ & $\begin{array}{l}\text { 1.0B.87.PF } \\
\text {-W2 }\end{array}$ & $\begin{array}{l}\text { Excision partial, spleen using open posterior } \\
\text { [subcostal] approach using collagen powder }\end{array}$ \\
\hline $\begin{array}{l}10 B 87 P F W \\
3\end{array}$ & $\begin{array}{l}\text { 1.0B.87.PF } \\
\text {-W3 }\end{array}$ & $\begin{array}{l}\text { Excision partial, spleen using open posterior } \\
\text { [subcostal] approach using fibrin glue }\end{array}$ \\
\hline 10B87PFX7 & $\begin{array}{l}\text { 1.OB.87.PF } \\
-\mathrm{X} 7\end{array}$ & $\begin{array}{l}\text { Excision partial, spleen using open posterior } \\
\text { [subcostal] approach using chemical cautery agent } \\
\text { [e.g. topical thrombin] }\end{array}$ \\
\hline $\begin{array}{l}\text { 10B87PFXX } \\
\text { E }\end{array}$ & $\begin{array}{l}\text { 1.OB.87.PF } \\
-X X-E\end{array}$ & $\begin{array}{l}\text { Excision partial, spleen using open posterior } \\
\text { [subcostal] approach using local flap [e.g. omental } \\
\text { wrap] }\end{array}$ \\
\hline $\begin{array}{l}\text { 10B87PFXX } \\
\mathrm{N}\end{array}$ & $\begin{array}{l}\text { 1.OB.87.PF } \\
-\mathrm{XX}-\mathrm{N}\end{array}$ & $\begin{array}{l}\text { Excision partial, spleen using open posterior } \\
\text { [subcostal] approach using synthetic tissue [e.g. } \\
\text { mesh] }\end{array}$ \\
\hline
\end{tabular}




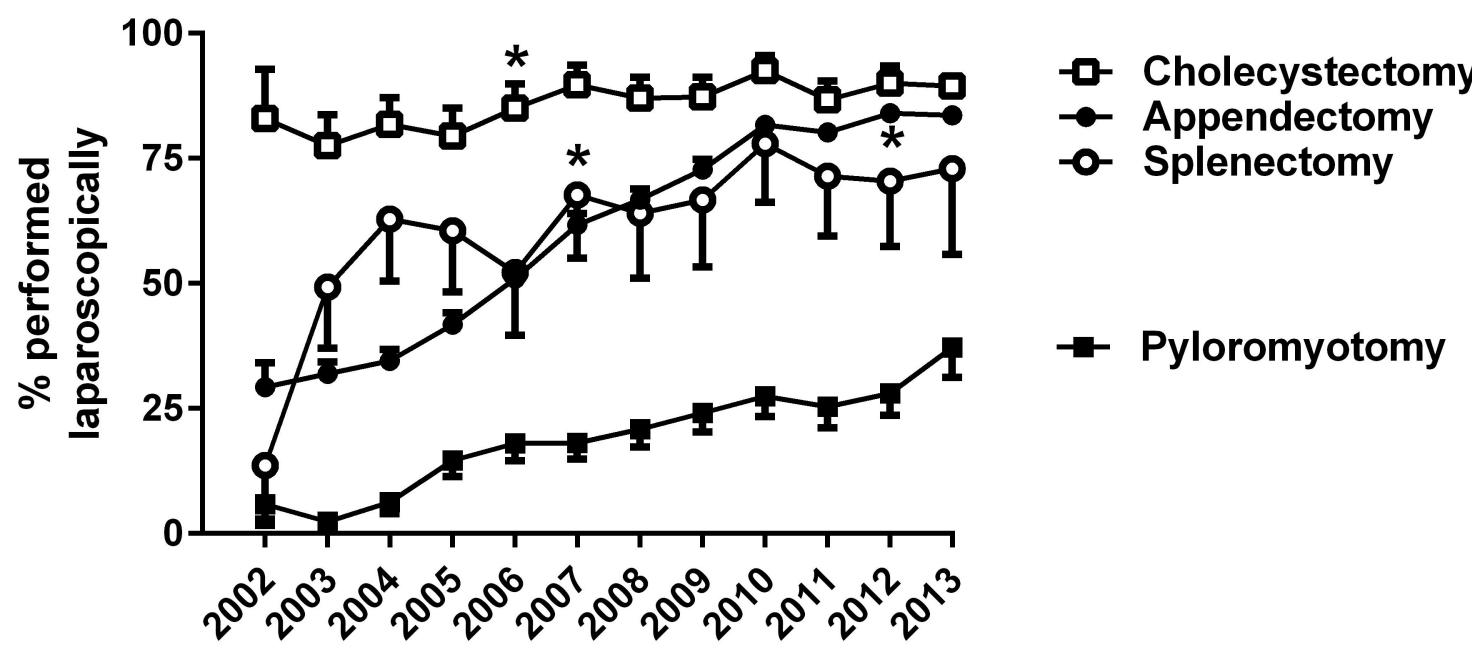




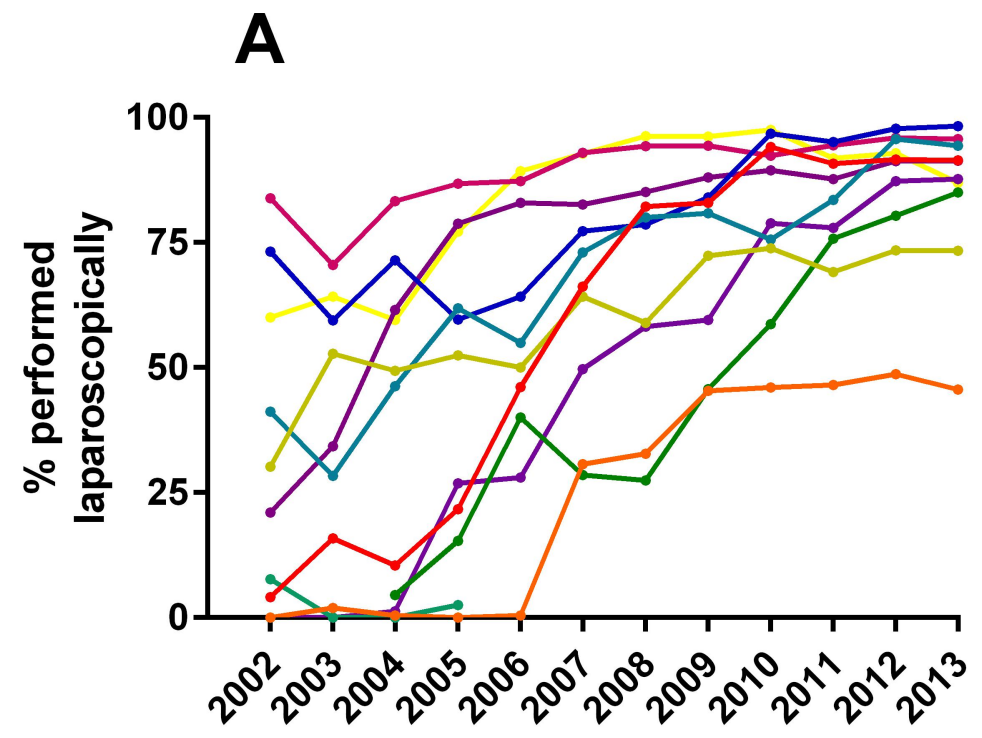

$\rightarrow$ Centre A

$\rightarrow$ Centre B

$\rightarrow$ Centre C

$\rightarrow$ Centre D

$\rightarrow$ Centre E

$\rightarrow$ Centre F

$\rightarrow$ Centre G

$\rightarrow$ Centre $\mathrm{H}$

$\rightarrow$ Centre I

$\rightarrow$ Centre J Centre K
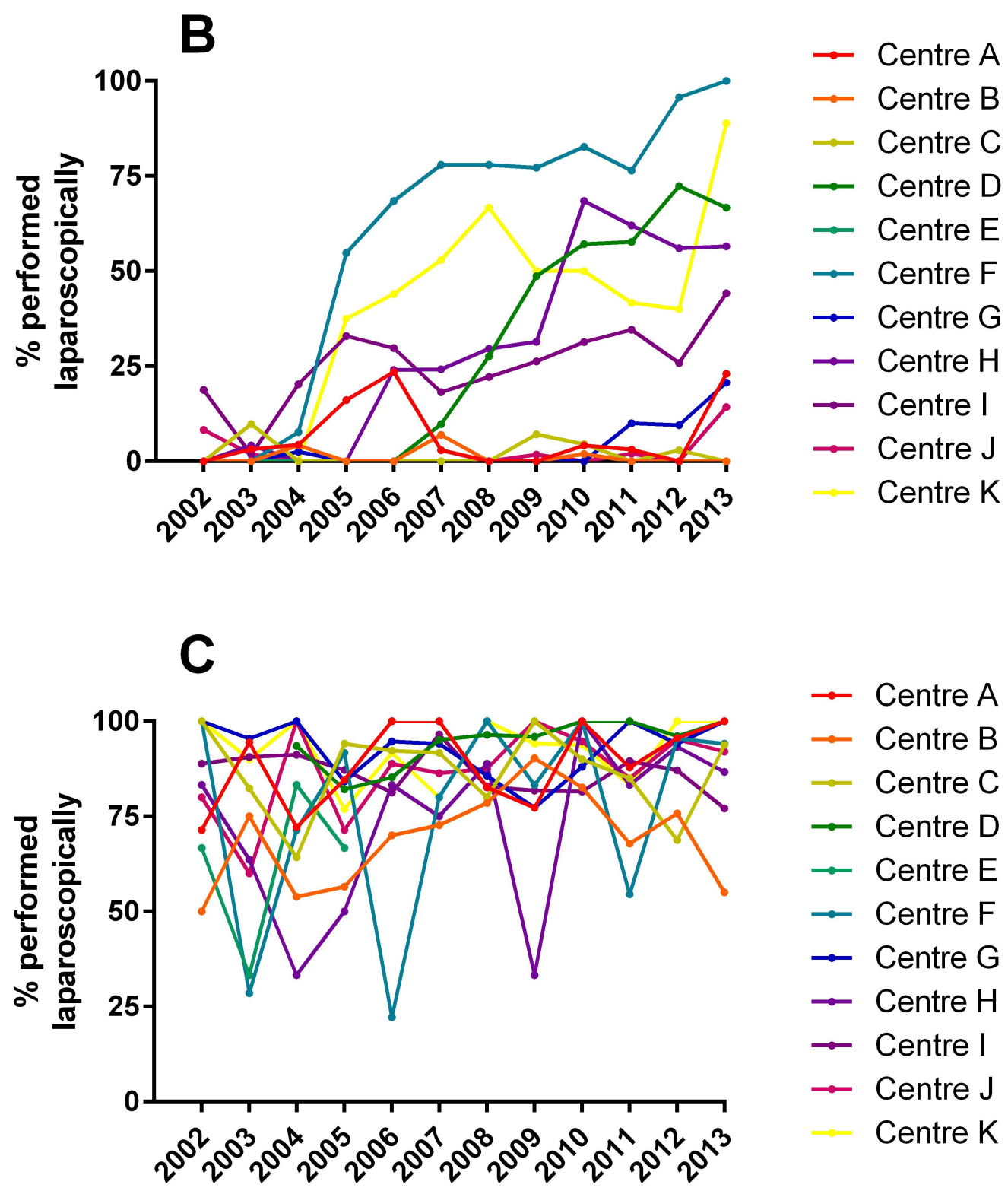